\title{
ROMANER
}

\section{Georg Christoph Lichtenberg}

Romaner. Vor levemåde er efterhånden blevet så ligefrem og alle vore skikke så tomme for mystik, vore byer er for størstedelen så små, landet så øde, alt er så enfoldigt sig selv lig, at den, der vil skrive en tysk roman knap nok ved, hvorledes han skal få bragt nogle figurer sammen eller få knyttet et par knuder. Thi, nu hvor tyske forældre selv opfostrer deres børn, er børneforvekslingernes tid forbi, og en kilde til opdigtning, som ikke lader sig betale for penge, er dermed tørret ud. Hvis jeg fandt på at lade et pigebarn løbe omkring klædt ud som en mand, ville det straks sive ud, og tjenestefolkene ville have røbet det, endnu inden hun var nået uden for en dør, og desuden er opdragelsen af fruentimmerne så kvindagtig, at de slet ikke kan bringes til at gøre noget sådant. Nej, at sidde artigt ved mamas side, at sy og lave mad for selv at blive en rigtig madmor, det er deres bestemmelse, ja vist, det er commode for dem, men en skændsel for fædrelandet og en uoverstigelig forhindring for romanforfatterne. Så fremdeles er man i England af den formening, at hvis to af samme køn deler værelse om natten, vil de uundgåeligt pådrage sig en fængselsfeber, hvorfor mennesker, som bor i samme hus, for det meste opholder sig alene om natten, og forfatteren behøver kun at bekymre sig om, hvordan han skal få yderdøren på

klem, så kan han iøvrigt slippe hvem som helst ind i huset, og han behøver ikke tænke på, om andre end den rette bliver vækket. End- 
videre, da de engelske skorstene ikke blot virker som røgkanaler, men først og fremmest som udluftningskanaler for sovekamrene, udgør de samtidig en fortræffelig mulighed for at trænge diskret og aldeles lydløst ind i hvilket som helst værelse i huset, ja det er så bekvemt, har jeg ladet mig fortælle, at hvem der een gang har taget turen ind og ud igennem skorstenen, næsten ville foretrække den frem for trappen. I Tyskland ville en bejler blive godt modtaget, hvis hân kom på at klatre gennem skorstenen, ja hvis altså han har mod på at havne i et ildsted eller en vaskekeddelfuld lud eller en Antichambre på 2 til 3 ovne, som man vel ikke engang kan åbne indefra. $\mathrm{Og}$ forudsat man således lader elskeren stige ned igennem køkkenet, er det stadig et spørgsmål, hvordan man får ham bragt op på taget. De tyske hankatte kan vel nok tilbagelægge denne vej til deres udkårne, men ikke de tyske mænd. I England derimod udgør tagene en slags gade, det til tider er bedre end den på jorden, og når man befinder sig på den ene er det ikke mere besværligt at finde over på den anden end at springe over en landsbyrendesten om vinteren. Det hævdes ganske vist, at man har indrettet sig således af hensyn til brandfaren, men da der næppe opstår brand i noget hus så meget som hver halvtredsindstyvende år, forestiller jeg mig snarere, at man har betragtet denne indretning som en nyttig trøst for nødstedte bejlere og tyveknægte, der, nøjagtig ligesom heksene og djævlen i Tyskland, meget ofte vælger denne vej, i hvert fald hver gang de må gøre deres tilbagetog i en fart, skønt de lige så godt kunne vælge en anden. Endelig ligger der en sand forhindring i de tyske postmestres iøvrigt fine og prisværdige påhit med at indføre de yderst populære åbne møddingvogne, som i årets løb lader en utallig mængde kvinders dyd uberørt, i stedet for de engelske postvogne, i hvilke en frugtsommelig prinsesse hverken behøver at skamme sig eller frygte, at hun vækker nogens lyst. Thi hvilken skade de commode engelske postvogne og deres fortræffelige ruter forvolder, lader sig vanskeligt gøre op med ord. For det første kan en pige, der går ud om aftenen med sin bejler fra London, nå ti Frankrig, inden hendes fader vågner om morgenen, eller til Skot land, inden han får truffet nogen beslutning med sine slægtninge, hvilket betyder, at forfatteren hverken har brug for feer, tryllekunstnere eller talismænd, for selvom han så kun kan bringe parre så langt som til Charingcross eller Hydepark corner, så er de samme sikkerhed, som hvis de befandt sig i Weber Meleks kiste 1. Tyskland derimod kan faderen, også selvom han først på tredjedagen opdager, at hans datter er forsvundet, til enhver tid hente hende hjem igen på rutens tredje station, hvis blot han ved, at hun er rejst med posten. Endvidere er der stof til episoder i de desværre alt for gode selskaber i de bekvemme postvogne i England, som altid er fulde af smukke velklædte fruentimmer, og hvor, hvad regeringen ikke burde tillade, passagererne er således placeret, at de ikke kan undgå at betragte hinanden, hvilket blot fremkalder en yderst farlig forvirring af blikke, men tillige en aldeles uanstændig og ophidsende forvikling af ben, som vækker smil på begge sider, og alt dette forårsager en forstyrrelse af sjæl og tanke, som ofte ikke vil lægge sig igen, hvorfor mangen et anstændigt ungt menneske, der agtede at rejse fra London til Oxford, er rejst ad helvede til. Sådan noget forekommer Himlen være lovet ikke i vore postvogne. Thi for det første kan et pænt fruentimmer umuligt komme op i vore vogne, hvis ikke hun i sin ungdom har øvet sig i at klatre over plankeværker, samle skadereder, hugge æbler og slå nødder ned, for det kræver en særlig Adresse at svinge sig op over vognfjælen og de færreste uerfarne fruentimmer-vil kunne gøre det uden bukser på, hvis ikke de vil give vognmesteren og staldknægten nedenfor en god latter. For det andet sidder man ikke ansigt til ansigt, når endelig man sidder, og i denne stilling er det, uanset hvad man iøvrigt måtte have imod den, i det mindste ikke let at starte en intrige, samtalen mister alt sit krydderi, og man kan højest forstå, hvad man siger, men ikke hvad man ønsker at sige; endelig er der helt andre ting at foretage sig i de tyske postvogne end at sludre, man må holde fast, når man kører over et hul i vejen, eller i værste fald være beredt på at springe af; man må være på vagt over for grene, og bukke sig i rette tid, hvis hat eller hovede skal blive siddende; man må være opmærksom på vindens retning og altid forstærke sin beklædning på den side, hvor angrebet sætter ind, og regner det sågar, så deler mennesket som bekendt den egenskab med andre dyr, som ikke lever i eller på vandet, at det bliver tavst, når det bliver vådt, og så går underholdningen helt i stå, og når endelig man når frem til et gæstgiveri, så går tiden med helt andre ting, den ene tørrer sig, den anden skutter sig, den ene sutter på sine brystbolsjer og den anden lægger varmt omslag på ballerne og hvilke barnagtigheder, der ellers tænkes kan. Således forsvinder postvognsintrigerne aldeles sammen med postvognene, der virkede som sande drivhuse for episoder og opdagelser. Men der findes da en postvogn ovre omkring Hannover, vil man så hævde. Javist, jeg ved besked, og det drejer sig endda om en postvogn, der er akkurat så god som de engelske. Man bør altså lade alle romaner begynde på strækningen imellem Haarburg og Münden, som idag bliver tilbagelagt med så stor fart, at man knap nok har tid til at lære hinanden rigtigt at kende, og alt, hvad de fremmede gọr, er at bryde ud i en lovprisning af kongen, som står bag alt dette, eller at sove, for førend de har sat sig i denne 
vogn, er de, sædvanligvis fra Hessen, Holstein eller Eichfeld, indstillet på at opføre sig, som om de var hjemme eller lå i sengen, når de befinder sig i en postvogn. Det er i sandhed godt stof for en roman at indføre 5 sovende og snorkende købmænd eller at fylde et kapitel med en lovprisning af kongen, hvilket der alligevel er tilstrækkeligt af i Tyskland. Det første er simpelt hen slet ikke noget tema for en bog, og det andet er ikke noget for en roman. Ja, hvad kommer det romanforfatterne ved? Robertson eller Hume eller Schlötzer ${ }^{2}$ kan bilde efterverdenen så meget ind om disse ting, som de vil. Men det har ikke noget med sagen at gøre, som jeg igennem jeres uoverlagte indfald er blevet næsten helt afsporet fra. Ja, hvis ikke der stadig fandtes et kloster her og der, hvor man kan lade et par elskende tage ophold, så ville jeg ikke vide, hvorledes jeg skulle strække en rigtig tysk roman så langt som til side tre. Og når engang der ingen klostre findes mere, så er timen inde for de tyske romaner.

Noter

1. Weber Melek, se den 111. dag i De persiske eventyr.

2. Lichtenberg stiller romanforfatterne op imod følgende historikere: William Robertson (1721-1793), David Hume (1711-1776), Johann Christoph Gatherer (1727-1799), August Ludwig von Schlözer (1775-1809)

Teksten er fra: G. C. Lichtenbergs Aphorismen. Nach den Handschriften hg. v. A. Leitzmann. Drittes Heft: 1775-1779. Berlin 1906, s. $36-40$. W 107.

Oversat af Dorthe Jørensen 